\title{
Social- Personal Characteristics of Farmers in Conservation of Traditional Sorghum and Minor Millets Crop Varieties in North-Eastern Karnataka
}

\author{
V. Chinmayi", S. B. Goudappa, D. M. Chandargi, Basavaraj Hulagur, \\ I. Shankergouda and D. H. Patil
}

Department of Agricultural Extension Education, UAS, Raichur -584103, Karnataka, India

*Corresponding author

\section{A B S T R A C T}

Keywords

Farming community, Socialpersonal, Traditional crop

Article Info

\section{Accepted:}

15 November 2019

Available Online:

10 December 2019
Present study focused to investigate social-personal characteristics of farmers conserving traditional crop in six districts of North-Eastern Karnataka which constitutes of 30 respondents with the help of snowball technique. Data were collected through personal interview with the help of interview schedule. The results revealed that majority of the respondents were middle age category, educated upto middle school level, having farming experience more than 25 years. Nearly sixty percentage of respondents were belonged to medium farmers having 5 to 25 acre in this only 40.00 per cent of farmers were growing traditional crop in less than and equal to 2.9 acres. With regard to experience in conservation and cultivation of traditional crop varieties majority $(56.67 \%)$ of the farmers had more experience succeeded by medium experience $(30.00 \%)$ and 13.33 per cent of the farmers had less experience. It is seen that farmers involvement is ensured to highest order in conservation in all crop seeds. However still whole farming community is aware of benefits of traditional crop varieties through trainings and workshops must be organized by the various agencies, be it Government or Nongovernment or private.

\section{Introduction}

Conservation is the process of protecting an endangered plant or animal species in its natural habitat, either by protecting or cleaning up the habitat itself or by defending the species from predators. There are two basic conservation approaches for conservation of resources, namely in-situ and ex-situ conservation. In-situ means setting aside of natural reserves, where the species are allowed to remain in their ecosystems within a natural or properly managed ecological continuum. In one of the approaches, Farmer's field is an important place to maintain genetic variability of the crop which is called as farmer-led on-farm conservation approach. Since, these resources are important to 
farming communities not only for food production but also for their role in culture and tradition; moreover, for their sustainable livelihood. The ex-situ form of conservation includes, in a broad sense, the botanic gardens and storage of seed or vegetative material in gene banks (Hammer and Teklu, 2008). This kind of efforts is done by the organized institutions such as National Bureau of Plant Genetic Resources (NBPGR), The International Crops Research Institute for the Semi-Arid Tropics (ICRISAT), Consultative Group for International Agricultural Research (CGIAR) and International Board for Plant Genetic Resources (IBPGR).

In milieu, in our country conservation activity is taking place through different extension approaches; at individual approaches farmers are conserving different crops of traditional varieties in their own fields and with the support of family members. They are not only the custodians but also managers of the crop diversity and driven by survival motives involving issues, far from simple profit maximization and take decisions on the choice of crop and varieties to plant, produce seeds and select them for storage and planting (Bellon, 1996; Brush, 1991) and the traditional varieties with great feel, owing to the fact that, 'good taste', adaptability to their farming conditions and their little or no use of external input like fertilizers.

In group level approaches, farmers are farming and managing Community Seed Bank (CSBs) at their locality and also at institutional level and some of the NonGovernment Organisation (NGO's) like Green Foundation, Deccan Development Society (DDS), Navadhanya, Sahaja Samrudha (SS) and M.S. Swaminathan Research Foundation (MSSRF) are passionate about conservation work. In North-Eastern Karnataka sorghum and minor millet is the major staple food and is also valued greatly for other uses like poultry and animal feed. The landraces of sorghum, pearl millet and minor millets were continued to be maintained for cultural preferences and traditional practices by the farmers which could play an important role in the food security, income generation and food culture of the rural poor in the area. Keep this in mind, wished to the understanding of social-personal characteristics of farmers in North-Eastern Karnataka, especially in major sorghum and minor millet growing areas.

\section{Materials and Methods}

Research design is the most important and crucial aspect in extension science research. The Ex-post-facto-research design was used to the present study. The study was conducted in North-Eastern districts of Karnataka viz., Bidar, Kalaburagi, Raichur, Koppal, Ballari and Yadgir during the year 2018-19, based on criterion of cropping pattern and districts coming under the judistriction of University of Agricultural Sciences, Raichur. There is no secondary database on conservator cum cultivator of traditional varieties of sorghum and minor millet. To over this, an effort was made to collect the information on sorghum and minor millet cultivator with the consultation of the officials of the Department of Agriculture, Non-Government organisations, progressive and award winners farmers in the study area. In order to identify the respondents who had actually cultivated at least one or more of traditional varieties from last five years i.e., 2013-14 to 2018-2019, a list of farmers were prepared and considered as respondents. After socialization process with selected respondents and were asked to provide names of farm families in their neighborhood or locality who are engaged in conservation of traditional sorghum and minor millets varieties. This procedure continued till the appropriate sample size is achieved. A sample size of 30 farmers who cultivate traditional sorghum and minor millets 
varieties were identified as respondents by following the principle of the snowball techniques. The farmers were categorized and scoring of responses of the respondents was done and categorized into three groups low size, medium and high size of land based on mean and standard deviation.

\section{Results and Discussion}

\section{Age}

It could be noticed from the Table 1 that, nearly two third $(63.33 \%)$ of the farmers belonged to middle age category (31 to 50 years) followed by old age category (27.77 $\%)$. It also observed that none of the farmers belonged to young age category. The results indicated that, farmers who involved in cultivation of traditional varieties belonged to middle and old age category. It clearly indicated that farmers even today they have a belief in traditional crop varieties and they have awareness about the importance of such crops which makes them to continuing cultivation of these crops. The farmers from younger age group have not shown any interest towards traditional crop cultivation, because younger farmers are getting attracted towards new technologies which make them to get a more profit over traditional crops. This is in line with the findings of Bhagubhai (2017) and Mathieu et al., (2017).

\section{Education}

A cursory look in Table 1 depicted that, more than one fourth $(26.67 \%)$ of the farmers educated up to middle school followed by equal $(20.00 \%)$ per cent of farmers had high school and pre university education, respectively while more than one tenth (16.67 $\%)$ per cent of farmers were illiterates and degree graduates respectively. It implicated that, as per age of the farmers majority of farmers belonged to middle age ( 31 to 50 ) and old age. It is self explainable that during their earlier days getting higher education was not their priority rather than taking farming responsibilities was more important for them than continuing with their higher education at the age of 12 to 15 . The economic status and socio-cultural backgrounds of their families could also strong reasons towards this observation. Only five farmers were educated upto degree levels because they were younger in the family. Similar findings reported by Roshini and Priyankara (2016).

\section{Size of land holding}

It was noticed that about 63.33 per cent of the farmers belonged to medium farmers ( 5 to 25 acre) had considered agriculture as their main occupation of the family and depend on their land for their livelihood. So, they always use to possess more acres of land. Among NorthEastern Karnataka people had large acres of land which was transferred from their ancestors followed by 26.67 per cent of farmers belonged to large farmers, who belongs to joint families. Usually in joint families land will be under the control of their head of the family. Whereas, Only 10.00 per cent of farmers belongs to small farmer category this is because these farmers sold their land to others because of their personal problems (children's education etc.). Above results contrary with Brush(1991).

\section{Cultivation of traditional crop in acres}

It also observed that in Table 1, that 40.00 per cent of farmers were growing traditional crop in less than and equal to 2.9 acres followed by 36.67 and 23.33 per cent of farmers grown in 2.91 to 5.67 acres and more than and equal to 5.68 acres respectively.

Because these crops were grown for only consumption and fodder purposes and also area has been replaced by other field crops 
which has higher market premium prize (example cotton) thus majority of the farmers were grown in limited acres compared to high yielding crop varieties. Remaining 23.33 per cent of farmers grow traditional varieties in larger area because these farmers fully depend on traditional farming alone.

\section{Family size}

The results depicted that nearly two third $(70.00 \%)$ of the farmers belongs to medium (4-6 members) sized family category. The main reason for this could be, now a day in rural areas families also became nuclear family which comprising father, mother and their children's due to some family disputes. More than one fourth $(26.67 \%)$ of farmers belongs to big family category (7-9 members) this is due to some of the families still living as joint family and higher size of land holding and 03.33 per cent of the farmers belongs to small family size category (2-3 members). Similar findings also reported by Rajesh and Sharma (2018).

\section{Farming experience}

Majority (70.00\%) of the farmers had more farming experience ( $>25$ years) and as per their education level majority of farmers studied up to middle and high school i.e., at the age of 15 only farmers started their farming practices, succeeded by 30.00 per cent of farmers had medium farming experience (15 to 25 years) this is because of farmers studied upto PUC and degree level and get joined different jobs. Then soon after their father passed away they came back to farming.

\section{Experience in conservation and cultivation of traditional crop varieties}

With regard to experience in conservation and cultivation of traditional crop varieties (Table $1)$, majority $(56.67 \%)$ of the farmers had more experience succeeded by medium experience $(30.00 \%)$ and 13.33 per cent of the farmers had less experience in conservation and cultivation of traditional crop.

This might be due that, in North-Eastern Karnataka region sorghum is a staple crop and which makes them to preserve sorghum crop from the ancient time. On the other side, only 13.33 per cent of had low experience because these farmers turned for traditional farming mainly due to the influence of Nongovernmental organizations (NGOs) or exposure visit.

\section{Annual income}

More than two fifth $(43.33 \%)$ of the farmers belonged to medium income group followed by high and low income group i.e., 30.00 and 26.67 per cent respectively. The possible reason could be, farmers had taken up both kharif and rabi crops in the study area, hence the income from crop production is higher.

In addition to this farmers also gained income from livestock and other occupations. In addition to this, few of the farmers growing Seetani jola to prepare Seetani (roasted sorghum), it has high demand value (Rs.200300 per kilogram) during November and December months which returns also adds to their annual income.

Similar observation was made by Shaila (2011), who found that majority of the respondents were belonged to high income categories.

\section{Social Participation}

The village organizations prevalent in the area were gram panchayat, agricultural cooperative societies, milk co-operative society etc., of which farmers were members or office bearers. 
Table.1 Distribution of farmers according to their socio-economic characteristics

\begin{tabular}{|c|c|c|c|}
\hline $\begin{array}{c}\text { Sl. } \\
\text { No. }\end{array}$ & Variables & Frequency & Per cent \\
\hline \multirow[t]{3}{*}{1.} & \multicolumn{3}{|l|}{ Age } \\
\hline & Middle (31 to 50 years) & 19 & 63.33 \\
\hline & Old(>51 years) & 11 & 27.77 \\
\hline \multirow[t]{6}{*}{2.} & \multicolumn{3}{|c|}{ Education } \\
\hline & Illiterate & 05 & 16.67 \\
\hline & Up to middle school & 08 & 26.67 \\
\hline & High school & 06 & 20.00 \\
\hline & Pre university & 06 & 20.00 \\
\hline & Degree & 05 & 16.67 \\
\hline \multirow[t]{4}{*}{3.} & \multicolumn{3}{|c|}{ Size of land holding(acre) } \\
\hline & Small farmer (2.51 to 5.00$)$ & 03 & 10.00 \\
\hline & Medium farmers (5.01 to 25.00 ) & 19 & 63.33 \\
\hline & Large farmers $(\geq 25.00)$ & 08 & 26.67 \\
\hline \multirow[t]{4}{*}{ 3a. } & \multicolumn{3}{|c|}{ Cultivation of traditional crop in acres } \\
\hline & Low $(\leq 2.9)$ & 12 & 40.00 \\
\hline & Medium (2.91 to 5.67$)$ & 11 & 36.67 \\
\hline & $\operatorname{High}(\geq 5.68)$ & 07 & 23.33 \\
\hline \multirow[t]{4}{*}{4.} & \multicolumn{3}{|c|}{ Family size } \\
\hline & Small (2-3 members) & 01 & 03.33 \\
\hline & Medium (4-6members) & 21 & 70.00 \\
\hline & Large (7-9members) & 08 & 26.67 \\
\hline \multirow[t]{4}{*}{5.} & \multicolumn{3}{|c|}{ Farming experience } \\
\hline & Less farming experience $(<15$ years $)$ & 0 & 00.00 \\
\hline & Medium farming experience (15 to 25 years) & 09 & 30.00 \\
\hline & High farming experience( $>25$ years) & 21 & 70.00 \\
\hline \multirow[t]{4}{*}{ 5a. } & \multicolumn{3}{|c|}{ Experience in conservation and cultivation of traditional crop varieties } \\
\hline & Less experience $(<15$ years $)$ & 04 & 13.33 \\
\hline & Medium experience ( 15 to 25 years) & 09 & 30.00 \\
\hline & High experience( $>25$ years) & 17 & 56.67 \\
\hline \multirow[t]{4}{*}{6.} & Annual income & & \\
\hline & Low income level group $(<2.5$ lakh $)$ & 08 & 26.67 \\
\hline & Medium income level group(2.5-4lakh) & 13 & 43.33 \\
\hline & High income level group(>4lakh) & 09 & 30.00 \\
\hline
\end{tabular}


Fig.1 Distribution of farmers according to their social participation and extension contact

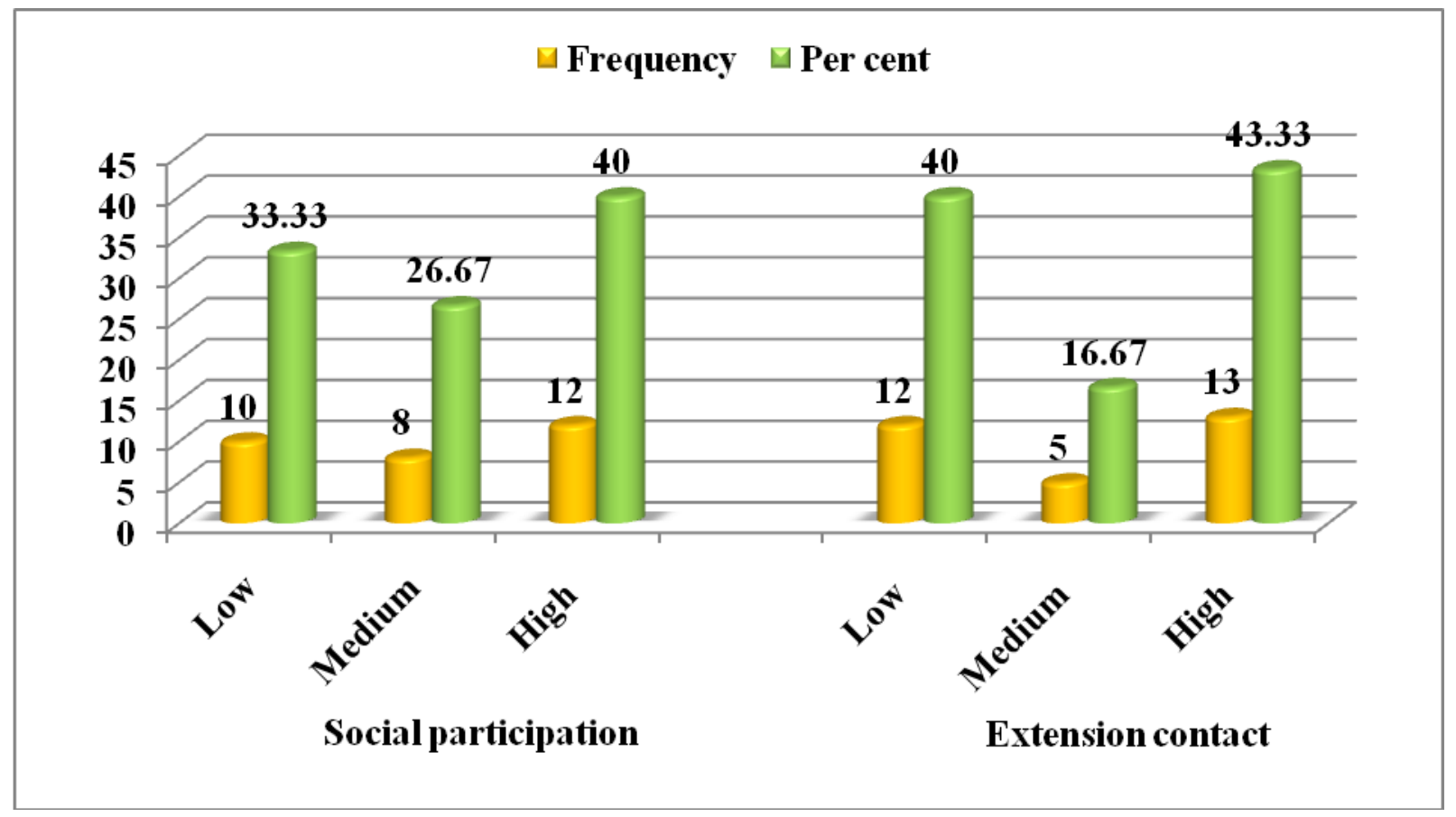

Fig.2 Distribution of farmers according to their extension participation and mass media utilization

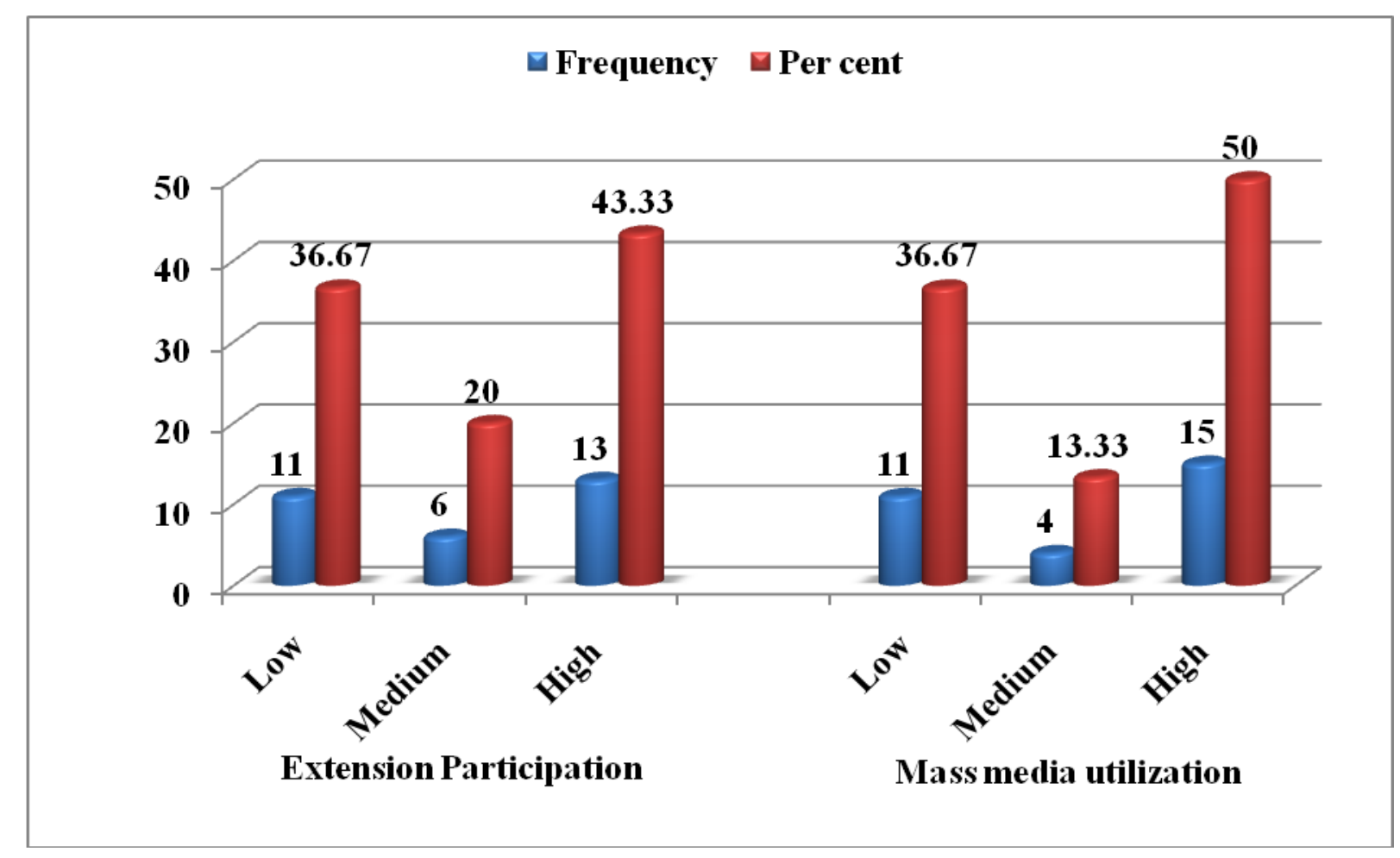


Table.2 Distribution of farmers according to their communication characteristics

\begin{tabular}{|c|c|c|c|}
\hline $\begin{array}{c}\text { Sl. } \\
\text { No. }\end{array}$ & Variables & Frequency & Per cent \\
\hline \multirow[t]{6}{*}{1.} & \multicolumn{3}{|c|}{ Social participation } \\
\hline & Membership & 27 & 90.00 \\
\hline & Non membership & 03 & 10.00 \\
\hline & Low & 10 & 33.33 \\
\hline & Medium & 08 & 26.67 \\
\hline & High & 12 & 40.00 \\
\hline \multicolumn{4}{|c|}{ Mean $=7.70$} \\
\hline 2. & & & \\
\hline \multicolumn{4}{|c|}{$\begin{array}{c}\text { Extension orientation } \\
\text { Extension contact }\end{array}$} \\
\hline \multirow{3}{*}{$a$} & Low & 12 & 40.00 \\
\hline & Medium & 05 & 16.67 \\
\hline & High & 13 & 43.33 \\
\hline \multicolumn{4}{|c|}{ Mean=12.90 } \\
\hline \multirow[t]{4}{*}{ b } & \multicolumn{3}{|c|}{ Extension participation } \\
\hline & Low & 11 & 36.67 \\
\hline & Medium & 06 & 20.00 \\
\hline & High & 13 & 43.33 \\
\hline \multicolumn{4}{|c|}{ Mean $=7.83$} \\
\hline \multirow[t]{4}{*}{3.} & \multicolumn{3}{|c|}{ Mass media utilization } \\
\hline & Low & 11 & 36.67 \\
\hline & Medium & 04 & 13.33 \\
\hline & High & 15 & 50.00 \\
\hline \multicolumn{4}{|c|}{ Mean $=8.10$} \\
\hline
\end{tabular}

The results of the Table 2 and figure 1 depict that, majority $(90.00 \%)$ of the farmers are active members in social organizations. Information was collected from the respondents, who reside in villages. Naturally, the farmers who stay in villages, at the age of 18 years became a member of a gram panchayat, few others may become the member of cooperative society. Around 10.00 per cent of farmers they don't have membership in any social organization. In case of social participation category, two fifth $(40.00 \%)$ of the farmers were actively involved in social organization as like president of gram panchayat, chairman religious committee, village heads in their respective villages thus one and the another way regularly participate in these social organization. Around 26.67 per cent of farmers were medium level involved in social participation succeeded by low social participation i.e., 33.33 per cent, because who belonged to medium and low category farmers occasionally visit to miles factory for processing of produce and agricultural cooperatives.

\section{Extension contact}

This is referred to as the degree to which an individual contact extension agencies to get information on agriculture and other aspects (Table 2 and Fig. 1). The distribution of farmers in case of extension contact, more 
than two fifth $(43.33 \%)$ of the farmers were coming under high extension contact category. As per our study be some of the farmers are opinion leader and innovator in their respective village which leads them to keeping good extension contact with the experts in regular interval. Forty per cent of the farmers had low extension contact, due to these farmers even today follow traditional practices in their field, because of their longer farming experiences which acclimatized with their farming practices. Those farmers were continued with their farming and not contacting extension agencies. Only 16.67 per cent of farmers had medium extension contact category with habit of contacting extension agents whenever they required. Similar findings line up with the Ede (2011) reported that respondents in their study area had contact with extension agents.

\section{Extension participation}

In Table 2 and Figure 2 it had noticed that more than two fifth $(43.33 \%)$ of the farmers belonged to high extension participation. Since they were opinion farmers they attended different extension programmes and trainings regularly and promoting the different agriculture practices to fellow farmers and succeeded by low extension participation $(36.67 \%)$ because of their strong belief in traditional farming or bad experiences with chemical farming might have led to continue with their traditional farming without attending the any extension programmes. Twenty per cent of the farmers had medium extension participation this could be the some of the farmers were regularly attending the only krishi mela but not to others extension activities. Results are contrary with Sunita (2008)

\section{Mass media utilization}

Mass media exposure is the degree of utilization of mass media by the respondents.
A number of mass media sources like newspaper, radio, television, internet etc. constitute this variable.

With respect to mass media utilization frequency, half per cent $(50.00 \%)$ of the farmers belonged to high mass media utilized category since the farmers belonged to high extension contact and high extension participation and more than one third per cent $(36.67 \%)$ of the farmers had low mass media utilized category which results line up with Jagadish (2007). More than one tenth (13.33 $\%$ ) of farmers were belonged to medium mass media utilized category (Table 2 and Fig. 2).

In conclusion that, the selected respondents were belonged to middle age category, educated up to middle school, medium farmers group, having experience of more than 25 years and members of one or more organizations existing in villages, high mass media category. It is seen that farmers involvement is ensured to highest order in conservation in all seeds crop. However still whole farming community is aware of benefits of traditional crop varieties through trainings and workshops must be organized by the various agencies, be it Government or Nongovernment or private.

\section{References}

Bellon, M. R., 1996. The dynamics of crop infraspecific diversity: A conceptual framework at the farmer level. Econ. Botany, 50:26-39.

Bhagubhai, T. A. 2017. An economic analysis of production and marketing of finger millet in Valsad and Dang districts of south Gujarat. M.Sc. (Agri.) Thesis, Navsari Agric. Univ., Navasari.

Brush, S. B. 1991. A farmer based approach to conserving crop germplasm. Econ. Botany, 45(2): 153-165.

Ede, D. E. 2011. Adoption of early maturing maize and cassava technology 
packages by farmers in Nkanu East and West of Enugu State, Nigeria. M.Sc. Thesis submitted to the School of Postgraduate Studies, Ahmadu Bello University, Zaria-Nigeria.

Hammer, K. and Teklu, Y., 2008. Plant genetic Resources: selected issues from genetic erosion to genetic engineering. J. Agric. Rural Dev. in the Trop. Subtropics, 109:15-50.

Jagadish, K. N. 2007. Documentation of indigenous practices followed by paddy growers of southern Karnataka. M.Sc.(Thesis), Univ. Agric. Sci., Bangalore.

Mathieu, A. T. A., Agyemang, D., Léonard, E. A. and Kwadwo, O. (2017). Utilization and farmers' knowledge on pigeonpea diversity in Benin, West Africa. $J$. Ethnobiology and Ethnomedicine, Open access, pp: 1-13.

Roshini, R. and Priyankara, E. A. C. 2016. Production and marketing of traditional Rice varieties in selected districts in Sri Lanka: Present Status and Future Prospects. Research report,
Hector Kobbekaduwa Agrarian Research and Training Institute, Colombo, Sri Lanka.

Rajesh, K. S. and Sharma, M. L. 2018. Small millets production and marketing trends of the tribal farmers in the Bastar plateau zone. Int. J. Curr. Microbiol. App. Sci., 7: 4078-4089.

Shaila, S. H. 2011. Evaluation of grain storage methods adopted by farmers. M.Sc. (Agri.) Thesis, Univ. Agril. Sci., Dharwad.

Singh, A. K. 2002. Role of Indian agricultural heritage in conservation and enhancement of plant genetic resources. In: Y.L. Nene and S.L. Choudhary (eds). Agricultural Heritage of India. Asian Agri-History Foundation, Secunderanad, Andhra Pradesh, India. Pp. 22-40.

Sunita, K. 2008. A study on indigenous technical knowledge of tribal farmers in agriculture of Jharkhand. M.Sc(Agri)Thesis, Sri Venkateswara Agricultural College, Acharya N.G. Ranga Agric. Univ., Tirupati.

\section{How to cite this article:}

Chinmayi, V., S. B. Goudappa, D. M. Chandargi, Basavaraj Hulagur, I. Shankergouda and Patil, D. H. 2019. Social- Personal Characteristics of Farmers in Conservation of Traditional Sorghum and Minor Millets Crop Varieties in North-Eastern Karnataka. Int.J.Curr.Microbiol.App.Sci. 8(12): 1719-1727. doi: https://doi.org/10.20546/ijcmas.2019.812.207 